\title{
Influence of Natural Resource-Based Conflicts on Security in Tana River County, Kenya
}

\author{
Douglas Fanuel Chikandah \\ Department of Security and Correction Science, Kenyatta University \\ Dr. Bernard Munyao Muiya \\ Department of Security and Correction Science, Kenyatta University
}

\begin{abstract}
Access to natural resources is increasingly being considered a security issues and cannot therefore be taken for granted. This is because natural resources normally occur alongside other conflict items like territory and regional predominance. In low-income countries like Kenya, access to natural resources is a serious issue especially when such countries lack enough capacity to deal with environmental challenges and scarcity. The study therefore assessed the influence of resource-based conflicts on security in Tana River County, Kenya. The specific objective was to assess the security threats associated with natural resource-based conflicts in Tana River County, Kenya. The study was underpinned by two theories; the structural conflict theory and the neoMalthusian theory. Through the mixed methods design (cross-sectional survey and phenomenology), data was collected through questionnaire, interview and focus group discussions. The sources of data were household heads in Ngao and Kilengwani divisions of Tana River County, Kenya. Other sources of data were sub-county police commanders and the ward commanders from the Kenya Police Service in Tana River County as well as the area County commissioner and his subsequent Deputy County commissioners. Sampling was through proportionate (household heads) and purposive (key informants) approaches. Quantitative data was analyzed through descriptive and inferential statistics and qualitative data thematically. The study established that natural resource-based conflicts is a frequent phenomenon in Tana River County as was observed by 97.9 per cent of the study participants. The study established that natural resources that led to frequent conflicts were water, pasture, and land. Three types of threats were linked to natural resource-based conflicts in Tana River County: personal, community and environmental security. Based on the stufy findings, it was recommended that the Ministry of Agriculture in collaboration with the Ministry of Water and Sanitation and Irrigation generate natural resources policies that will create the existence of sufficient water points in the hinterland. The two ministries should revive the collapsed irrigation schemes in order to create livelihoods for community members thus reducing the tensions between the dominant Pokomo and Orma communities.
\end{abstract}

Keywords: Natural Resource-Based Conflicts, security threats

DOI: $10.7176 / \mathrm{PPAR} / 11-5-05$

Publication date:June $30^{\text {th }} 2021$

\subsection{Background to the Study}

Natural resources conflicts can become pronounced especially when the resources are shared between countries or communities without adequate legal arrangements (Klare, 2002). There have been many global declarations over water, for instance, to ensure that conflicts do or arise. The United States Institute of Peace (2007) indicates that by 2006, 3,800 such declarations had been signed e.g., the Istanbul in turkey 5th water forum declaration of head of states over water among others.

The fact that many declarations or conventions exist on water is a clear demonstration of how natural resources can be a trigger of conflicts (Le Billon, 2005). Another reason why natural resources conflicts can be on the rise is due to the fact that resources have played an integral role in society both as a source of income and identity. This is increasingly so in low-and-middle income countries. This is due to the fact that such countries' major source of revenue is usually natural resources. Furthermore, natural resources function as a commodity in both the local and global economic structures (Frankel, 2010), making their use a challenge, particularly for African countries (Collier \& Hoeffler, 2009).

Conflicts over natural resources such as water, forests, minerals, and land have erupted in Kenya. Natural resource conflicts are distinct in that they affect the livelihoods of people who rely on both renewable and nonrenewable natural resources (Kirchner, 2013). Land, water, wood, minerals, metals, and oil, among other natural resources, are vital sources of life, revenue, and influence for governments and communities all over the world (Christine \& Will , 2010).

Natural resource-related conflicts can be attributed in part to a lack of effective conflict management mechanisms that are respected by various groups, communities, community developers, government, and other organizations involved in accessing and utilizing the resources (Owuor, Mauta, \& Eriksen, 2011). When natural resources are mismanaged or unequally distributed, or when commercial activities are carried out without 
appropriate care, tensions can rise, potentially leading to violent conflict. If not addressed properly, these disagreements may turn violent, degrade the environment, and jeopardize livelihoods (Jensen, Matthew, \& Brown, 2010).

Conflict in society is caused by rivalry over material products, ecological services, economic advantages, property, or power, according to Yulia, Alberto, Heijden, and Tim (2017); individuals feeling that their needs cannot be satisfied; and people's values, needs, or interests being threatened. Furthermore, population expansion and environmental degradation are intensifying competition for already scarce resources like land and water, with climate change threatening to exacerbate the situation (Josie Lianna Kaye, 2012).

Natural resource disputes emerge as a result of disagreements or unequal access to, control over, and usage of natural resources. Natural resource competition and a lack of established norms and regulations for using natural resources can lead to conflict. Rapid population increase, resource depletion, uneven resource access, and political instability are all factors that contribute to natural resource disputes.

The agropastoralist Pokomo and pastoralist Orma communities have been in sporadic conflicts since the 17th century (Kirchner, 2013). Over time, however, increasing environmental hardship has led to the heightened tensions between the two communities. Kirchner (2013) further states that "...disputes over crop damages and access to water had in 2012 led to violence between farmers and herders". The two communities have also blamed local security agencies including the National Police Service for mishandling the conflicts.

The process of attaining goals with a limited number of resources is known as management. Traditional management theory based on the concepts of planning, organizing, staffing, directing, and controlling (POSDC) and popular management theory based on the principles of management into planning, organizing, leading, and controlling (POLC) are two well-known approaches to management (POLC). As a result, security management will entail identifying and regulating the resources allocated to the country's security sector, as well as monitoring and changing the process as progress is made toward the aim of establishing a safe society and resolving resource-based disputes. (J. Anderson, 2016)

Security management also entails identifying community assets, such as people and high-value natural resources such as wood, diamonds, oil, and gold, as well as developing, documenting, and implementing rules and procedures to safeguard them. To detect threats, categorize assets, and grade system vulnerabilities, an organization employs security management techniques such as information categorization, threat assessment, risk assessment, and risk analysis (Wallensteen $\mathrm{p}$ 2007).

Due to resource-based conflicts, the global and regional security environment continues to face dynamic challenges and possibilities that necessitate innovative responses. As a result, most governments throughout the world, including the Commonwealth, have switched to 21 st-century dynamic security management methods, and Kenya is no different. Kenya has been impacted by resource-based conflicts, which has prompted a paradigm shift in our police philosophy. An effective policing strategy is critical in establishing a framework that allows community members to engage in the security of themselves, their assets, and national interests in order to manage the ever-increasing conflicts that arise as a result of natural resource extraction. (Laue, J.H 1993).

The constitutional handling of natural resources, on the other hand, in split societies is primarily concerned with how natural-resource wealth is shared across sometimes hostile populations. Conflicts do not occur in a vacuum, and they are heavily influenced by the circumstances. Indeed, it has been suggested that natural resource governance is particularly essential in split communities since control over the advantages derived from local natural resources is frequently a primary driver of ethnic or identity-based conflicts. Natural resource disputes are also linked to and/or influence human development considerations, particularly the drive for socialeconomic progress, both directly and indirectly. (Sachs J.D \& Warner, 2001)

This relationship is recognized in the Sustainable Development Goals (SDGs) because sustainable development cannot take place without peace and security; and peace and security without sustainable development are at danger. The SDGs say that the new agenda acknowledges the need for a peaceful, fair and inclusive society that provides equal access to the courts and that is based on respect for human rights, effective rule of right and good governance, transparent, effective and responsible institutions at all levels (Yamano, et al. 2005)

The Agenda addresses factors that contribute to violence, instability, and injustice, including as inequality, corruption, inadequate governance, and illegal money and weaponry flows. The goal is to step up efforts to settle or avoid conflict, as well as to assist post-conflict countries, especially by ensuring that women have a role in peacebuilding and statebuilding. It calls for more effective steps and measures to be taken, in line with international law, to eliminate barriers to the full exercise, in particular in respect to the economic and social development, of the right to self-determination of peoples under colonial and foreign occupations. Conflict management should thus be one of the main challenges facing the search for sustainable development(Warner, M. 2000).

It is apparent from the above that natural resources such as land, water, wood, minerals, metals and oil are vital sources for a community's livelihood and also revenue generators. This impacts countries and communities 
worldwide which have such resources. If natural resources are poorly managed or unequivocally shared, commercial operations can lead to tensions that might progress towards severe violent clashes or nurture and aggravate pre-existing conflict differences without taking into account reality and communities' context and requireations (Tyler, S.R 2016).

Increased competition for already scarce resources such as land and water is growing as a result of population expansion and environmental degradation, and climate change threatens to exacerbate this rivalry. The study shall therefore examine the influence of natural resources conflicts on security management in Kenya and ways of managing such conflicts to maintain peace and security in the affected areas as well as information related sectors e.g. policy-making sectors from grass-root to national leadership and contribute information to the academic sector (Yamano, et al., 2016).

The economic marginalization in Tana River County can partly be comparable to other African regions like the Sahel. With a population growth rate of 2.8 percent, the county has $76.9 \%$ of its inhabitants living in absolute poverty (Katembu, Miriti, \& Carranza, 2017). This rate of population growth is very likely to have a direct influence on natural resource availability and usage. The region has seen conflict between farmers and herders as a result of natural resource management, pitting the pastoralist Orma group against the agropastoralist Pokomo population.; thus it is important to establish how this has influenced security in the region.

\subsection{Statement of the Problem}

When communities or groups interact with one another in terms of "mobility, trade and access to natural resources, there are important implications for social equity" (Eriksen et al., 2011). These interactions are linked to environmental integrity which is one of the key aspects of sustainable adaptation in Tana River County, the Orma and Pokomo communities interact more so in access to natural resource use. The two group have had shared reliance on the River Tana. The Pokomo are mainly s agriculturalists and fishermen, living along the River Tana. On the other hand, the Orma are nomadic pastoralists living on the lower banks of the Tana and frequently move from one place to another in search of pasture and water for their livestock. In the process, there is occasional ranging onto Pokomo lands creates natural tensions between them. Natural resource conflicts have severe impacts on both humans and the security of the area.

There is an increasing interconnection between natural resources use and conflicts. For example, there is a link between food, land, and hydrological systems. In this regard, when any of them is affected in terms of availability, there are implications in terms of political as well as national or regional security. This implies that the security of nations or regions increasingly depends on the security of natural resources. Local economies like in Tana River rely on the availability of these resources like portable water or arable land. The question that need interrogation is whether the security community at both national and county levels can conciliate the security challenges posed by natural resource use.

More often than not, the security community both globally and at the local level has not fully "integrated resource concerns into their work" (Christineand \& Will, 2010). It is highly likely that there is no framework to consider natural resources in the operations of security agencies in Kenya, both at the national and county levels. An if such framework exists, then, it could be weak or non-operational. Thus, there is need to have a strong understanding on the role natural resources play in conflicts. The global security community is quite versed with and pays due attention to non-renewable resources like oil and minerals.

Despite efforts to resolve the resource conflicts in the study area no positive results have been earned even with the various efforts put in place by the government. Some of the efforts include increased deployment of security agencies to arrest and prosecution of violent perpetrators. There have also been peace mediation meetings by the Orma and Pokomo communities, impromptu security checks as part of illegal arms crackdown missions and forced disarmament. There have been initiatives by non-governmental organizations (NGOs) to defuse tensions between the two communities. The Restoration Initiative by International Union for Conservation of Nature (IUCN), the Food and Agriculture Organization (FAO) of the UN, and the UN Environment Programme is a good case in point (Nicholas, Jacqueline, \& Simon , 2019). This was a US\$250million project meant to rebalance the Tana Delta Ecosystem; and thus, expected to defuse local tensions in Tana River County. The Kenya Land Alliance (KLA) and Oxfam have also partnered in 2015 to implement community land protection approach in Tana River County ( Brinkhurst, 2015). The scope of the initiative was enshrined in four objectives which included documenting and protecting lands of communities in Tana River County. Other objectives included resolving longstanding conflicts as well as help communities chart a course towards peaceful co-existence and collective land management.

Research gaps still exist as most existing research has concentrated on the causes of conflicts and scarce attention is given to the influence of natural resources conflicts on security management. This then shows that there is need for research to address issues surrounding the interconnectedness between natural resources, particularly renewable natural resources. An understanding of the link between the two shall offer an opportunity to deal with the recurring conflicts effectively; by examining the influence of natural resource conflicts to 
security in Tana River County.

\subsection{Objectives of the Study}

The general objective of the study was to investigate the influence of natural resources conflicts on security in Tana River County, Kenya.

\subsubsection{Specific objective of the Study}

Assess the security threats associated with natural resource-based conflicts in Tana River County.

\subsection{Research Question}

What are the security threats associated with natural resource-based conflicts in Tana River County?

\subsection{Significance and Justification of the Study}

In Africa, most conflicts are often attributed to competition over natural resources. A good case is the Sudan region of Darfur where there has been a long history of conflicts between farmers and pastoralists over access to land, In Kenya, Tana River County, the conflict has a long way history back from the 17th Century when the first settlements happened along Tana River (Hunink, Niadas, Antonaropoulos, Droogers, \& De Vente, 2013). It remains a conflict hotspot area due to long-running perennial conflicts between the indigenous farming community and nomadic pastoralist. A good case study is the attack of Reketa village, in Kipini location within Tana Delta Sub County where on 22 august 2013, 52 people were killed as a result of disputed land rights between the Orma and the Pokomos. Nation team 2013) The attack was fueled by an attack by ormas who had invaded farms belonging to the Pokomo community. Those who did the attack were fully armed with bows and arrows, Matchets and firearms, On the 10th September 2013, at Kilelengwani area within the same Kipini location within Tana Delta Sub County, 38 people were killed including nine police officers from the General Service Unit and two Administration police officers who were deployed on a peace security mission. The state reacted through a motion that was raised in parliament by the then Garsen constituency Member of Parliament Hon Danson Mungatana on forced disarmament. All these strategic measures were put in place, but still incidences have been witnessed on resources conflicts between the two communities. Therefore, the findings of this study will be of great importance to Policy makers, Community members and Academicians on the influence of resources-based conflicts and how it is a security management dilemma in Tana River County. The study further provides a base upon which other studies can be conducted in other parts of the country on natural resources related conflicts and how they can be managed.

\subsection{Literature Review}

\subsubsection{Overview of Resources-Based Conflicts}

Oil, minerals, forests, water, and fertile land are all examples of natural resources that may be utilized for economic advantage. These resources are typically major sources of wealth and power; land, in particular, is critical to millions of people's livelihoods. Natural resources may be a major source of conflict or instability when they are mismanaged, dispersed, or controlled in an unjust or uneven manner. Conflicts over resources are usually classified according to the principal resource involved and the key conflict driver. Extractive resources (such as hydrocarbons, minerals, gemstones, and wood), land, and water are common resource types. Many disputes, of course, involve the interaction of many types of resources. In fact, one or more of the following drivers are at work in the majority of cases: (1) conflict over resource ownership; (2) conflict over resource access; (3) conflict over resource management decision-making; and (4) conflict over the distribution of resource revenues as well as other benefits and burdens (UNEP, 2013).

The United Nations Security Council (2017) reports that globally, there are varied and numerous resourcebased conflicts to deal with. These conflicts range from territorial, interstate and domestic disputes. The world today is grappling with resource-based conflicts, which remain the most pressing in the international relations perception. As a source of revenue, industry and identity, natural resources are an important component of society. As their principal source of revenue, developing nations are more dependent on natural resources and many people rely on these resources for their lives. Half of the world's populations are projected to remain closely linked to local natural resources. Agriculture, fishing, minerals and wood are the major sources of income for many rural areas.

There is a direct link between Natural resources and social conflicts in Africa. This is because the said existing resources are vital and are of great significance as given by the existing relationship with social conflicts. Looking at the whole issue and from a broader outlook, it can be clearly observed that natural resources are implanted in the natural environment where any step taken by one individual, or group may have effects on other related areas or even extending to the National level or jurisdictions. This is specifically right because of the shared trans-boundary resources. The issue surrounding the Mau forest complex in Kenya is considered or regarded as a good point of reference. (Kaldor, 2015). 
Social conflict triggered by trans-boundary relationships can be traced back between Tanzania and Kenya over the Mara River basin. The Mara River is a basin shared between the two countries because of its origin from the Mau forest complex. This basin, also forms part of the larger Nile basin, which is shared by nine countries, namely Ethiopia, Sudan, Tanzania, Egypt Kenya, Uganda, Rwanda Burundi and the Democratic Republic of Congo (DRC). Because of the loss of Mau Forest cover, expansion of agriculture, population increase, socio-cultural and socio-economic actors in the Mara River basin have made the said basin to be water stressed.

Water scarcity is not the only challenge in this area. There are other issues touching on loss of virgin forest on the catchment areas, along the river basins, environmental criminal activities related to water pollution, industrial and urban settlement water use, environmental crimes related to water pollution, and high levels of water use by industries including urban built up areas. The said challenges have presented a number of environmental security dilemmas ranging from reduced water supply, competition for the said water resource, poor land use, and poor management of water as a vital and reliable resource. Therefore the use of natural resources has adverse effects to the organisms surrounding the said resource. The immediate consumer is finally affected by the said issues thereby bringing out the need for handling these issues critically in the natural resources platforms.

Disputes over resources are common, as are conflicts over political authority arising from a lack of security or psychological dread of political instability (Adedeji, 1990). As a result, the use of the Tana River's waters has been at the center of a dispute that pits these two groups against one another. Pastoralists return to the river during the dry season in search of water and grazing. Essentially, the Pokomo claim the land along the river and the Orma claim the waters of the river (Weiss, 2012). However, security demands that Tana River communities co-exist peacefully with the limited resources they each have to contend with (Adedeji, 1990). The escalation of the conflict has partly been linked to other factors such as political interests, incitement, lack of alternative livelihoods, high levels of poverty, breakdown of indigenous governance systems and inadequate security systems or policies (Mohamed, 2015). Violence in pastoralist areas has had a devastating socio-cultural, political, and economic impact on pastoralist communities, resulting in the loss of human lives and property, community displacement, economic and infrastructure breakdown, environmental degradation, and inter-ethnic hatred and mistrust (Mohamed, 2015).

\subsubsection{Weakened Traditional Governance on Security Management}

Traditional system of governance is "one of the ancient ways in which conflicts were resolved and gives the example of mediation being used in ancient China, Homer's Iliad (750BC) which justifies the existence of mediation" (Ho-Won , 2010" This author further argues that "if the conflict is protracted, has become more complex, or if the parties want to break their stalemate and avoid humanitarian crisis or if a negotiation has hit a deadlock, then mediation could be a last resort". Mediation is cheaper than other conflict management techniques like peace keeping, it is flexible since "it allows different views and can be adopted legitimately by the private citizens, any other actor, international organizations and also helps in constructive conflict management" (Ho-Won , 2010). Mwagiru (2012) argues that "traditional leaders have been given prominence in mediation of disputes especially in Africa and Asia". They are often perceived as leaders with wisdom to navigate negotiation process, they are also highly valued and regarded in our African institutions as important part of the African culture.

Land and grazing rights are at the root of the resource-based conflicts between the Pokomo and the Orma. Orma pastoralists accuse Pokomo farmers of denying them access to water and grazing grounds, while Pokomo farmers accuse pastoralists of grazing on their farms and damaging their crops (Badurdeen \& Omalenge, 2015).To resolve conflicts arising from tensions within the communities or between communities in the Tana River region, traditional mechanisms have been used by village elders. Traditional elder-led local peace meetings attempt to address resource-based conflicts that arise between the Pokomo and the Orma, particularly over access to water sources and pastures. Traditional methods, on the other hand, are losing their effectiveness in highly political environments. For example, it has been claimed that community elders who once had a good reputation have suddenly turned corrupt, causing the processes to lose trust (Badurdeen \& Omalenge, 2015).

Due to flaws in traditional conflict resolution processes, law enforcement officials are required to act anytime disputes emerge. When a result, efficient security management is critical as confrontations become politicized and exaggerated, taking on ethnic aspects. For example, ethnic violence erupted during the 2012/13 war, resulting in the deaths of 200 individuals and the displacement of hundreds more (Kirchner, 2013). According to Nyanchoga (2017), the war between the Orma and Pokomo tribes resulted in 118 fatalities and more than 13500 displacements, with an additional 30000 individuals affected by ethno-political conflicts. Over half of those displaced were youngsters, with the remainder being women and the elderly (Nyanchoga, 2017). Property was also lost, crops were destroyed, fallow ground was overgrazed, water supplies were contaminated by cattle, and pastoralists were harassed by farmer youths as a result of resource-based conflicts between communities in Tana River. Other outcomes include sexual harassment of women by either community, 
livestock theft, decreased productivity and revenue, and farmers and pastoralists being displaced (Badurdeen \& Omalenge, 2015).

\subsubsection{Conflict Interventions on Security Management}

Natural resource conflicts are expected to pose substantial challenges to global security, necessitating the development of a comprehensive plan to address and overcome these threats. This strategy should make better use of current tools and techniques while also developing new ways to reconcile the competing imperatives of natural resource access, market regulation, and conflict avoidance, mitigation, and resolution. A deeper knowledge of natural resource-related security and conflict issues, as well as a study of how present policies influence these difficulties, is required for such an approach. The strategy should be based on extensive research into the link between natural resources and conflict financing, the changing nature of state effectiveness in the context of natural resource agreements, the link between resource conflict and climate change, and the impact of natural resource conflict on the multipolar global economy.

Efficient frameworks exist on security management in conflict prone areas due to resource sharing. The Unifying Negotiation Framework (UNF) was advanced by Daniel, Walker, and Emborg (2012) as a tool of social negotiation among conflicting discourses providing a multi-faceted design of enhanced peace building process. This framework aids designers and implementers of security management to better put and investigate complex natural resource-based struggles that build firm foundations in redress of conflict challenges.

In Africa, there is a legal and institutional framework for dealing with natural resource disputes and either resolving or managing them. Courts of law, tribunals established under various Acts, the Environmental Complaints Committee, the Environment Tribunal, and other informal community-based resource governance organizations are among these institutions. Courts of law, both civil and criminal, Environment Tribunals, Arbitral tribunals, Statutory tribunals established under various laws, and customary law systems of conflict management are among the existing legal mechanisms for managing natural resource conflicts as enshrined in environmental law statutes. (Ejizu, 2016).

A bottom-up approach to natural resource management, including conflict resolution, allows local people to be involved who may have firsthand knowledge of the difficulties. As a result, this study argues for the employment of conflict resolution strategies that include public engagement. Litigation, which is a statesponsored strategy to dispute resolution, does not provide impacted parties with a reasonable and fair chance to participate in the development of a long-term solution. This is due to the fact that, in addition to the coercive aspect of the procedure, litigation is susceptible to additional procedural issues that may limit its efficacy (Ojwang, 2017).

National legal systems have been linked to a number of drawbacks, including inaccessibility to the poor, women, marginalized groups, and remote communities due to cost, distance, language barriers, political barriers, illiteracy, and discrimination; failure to consider indigenous knowledge, local institutions, and long-term community needs in decision-making; and the use of judicial review. To avoid the potentially harmful impacts of conflict in a society, conflicts must be handled through interactive, participative, and inclusive techniques aimed at balancing interests, power, and modifying parties' expectations. In order to guarantee a peaceful society where organizations do not unnecessarily utilize their power to crush perceived weak groups or people, a balance must be struck among the three component components of a dispute, namely goal incompatibility, attitudes, and conduct.

violence is a safety issue that has brought the Kenyan security sector to the fore. Institutional capacity, limited resources, a lack of expertise to tackle modern crime, and dwindling public faith in security agencies are all factors affecting Kenya's security situation (Nyanchoga, 2017). However, according to a recent research by Kariuki (2016), Kenya's constitution "envisages a scenario where conflicts, particularly those involving natural resources, should initially be resolved through Alternative Dispute Resolution (ADR) and (Traditional Dispute Resolution Mechanisms" (TDRMs). Nevertheless, there have been no real initiatives to take up these very widespread and reason for worry procedures in the management of natural resource disputes.

Processes for alternative dispute resolution (ADR) include mediation, conciliation, negotiation and conventional conflict resolution/community mechanisms. The benefits of ADR techniques include economical, speedy, informal and involved. Controversy and connections can be maintained between parties. Mechanisms for conflict management, such as mediation, foster 'win-win' situations, parties seek their own solutions, pursue interests rather than stringent legal rights, are informal, flexible and try to bring together all parties.

Kipkemoi et al. (2017) assert that the measures taken by government to solve conflict and address security management in Tana River County include holding peace meetings, disarmament, sending government officials and imposing curfews. Other actions include the installation of new police stations, the arrest of community members, the deployment of the General Service Unit (GSU), the formation of an investigation committee, and the delivery of food aid (Kipkemoi et al, 2017). The government has primarily dealt with resource-related disputes by deploying national security forces, arresting and prosecuting offenders through legal channels (Martin, 2012). As a result, security issues between the two groups should be based on local capabilities to 
manage resources and resolve problems (Weiss, 2004).

\subsubsection{Theoretical Framework}

The theoretical framework for this study was based on the premise that throughout history, struggles over territory has caused conflicts among communities. Ngwu and Chukumwa (2019) suggest that contemporary boundary disputes are motivated by the control, in part, of natural resources. The study adopted two theories: the structural conflict theory and the neo-Malthusian theory.

\subsubsection{The Structural Conflict Theory}

To appreciate the source of natural resources-based conflicts, the starting point would be to conceptualize social structure, a concept that represents a perspective of looking at the sociological universe. The concept of social structure was widely explored in the twentieth century, with significant contributions from Claude Lévi-Strauss' structuralist viewpoints and Talcott Parsons' functionalist perspectives (Martin \& Lee, 2015). Social structure stresses the concept that society is divided into structurally connected groups or sets of roles, each with various functions, meanings, or goals (Martin \& Lee, 2015). Important social systems, such as the economic, legal, political, and cultural systems, may be influenced by social structure. Thus, social structure can be considered as the patterned social arrangements in society. Such arrangements emanate from and are determinant of the actions of societal members. As (Fabrizio, Juan, \& Miguel , 2006) argue, any phenomenon we observe in any human society results from the social structure that unites such societies. The existing social structure in any society whether at the macro or micro level of society - determines the type of interaction and/or co-existence among members of the community.

The constant conflicts between the Orma and Pokomo communities in Tana River County can be explained through the theories of conflicts. These are perspectives that view societies from a materialistic point of view hence the existing social structures. Proponents of conflict theories draw their perspectives from Karl Marx social conflict theory, which is based on dialectical materialist account of history among groups. The materialist nature of societies can be explained by the structural theory of conflict. The theory has both the radical structural orientation represented by the Marxist dialectical school and liberal structuralism (Garltung, 1990; Ross, 1993). Natural resource-based conflicts can be explained through liberal structuralism. As Garltung (1990) argues, social structures in society can create structural violence when members of the society are prevented from meeting their basic needs. The concept of social structure was widely explored in the twentieth century, with significant contributions from Claude Lévi-Strauss' structuralist viewpoints and Talcott Parsons' functionalist perspectives (Martin \& Lee, 2015). Social structure stresses the concept that society is divided into structurally connected groups or sets of roles, each with various functions, meanings, or goals (Martin \& Lee, 2015). Important social systems, such as the economic, legal, political, and cultural systems, may be influenced by social structure.

This research takes Mills' point of view on conflict. Mills, who is widely regarded as the father of contemporary conflict theory (Knapp, 1994), believes that social institutions are formed via conflict between people with different goals and resources. Mills' viewpoint is expanded upon by Sears (Sears, 2008), who claims that civilizations are defined by the inequality that leads to conflict. In this sense, underprivileged individuals of a community are more likely to have structural interests that run opposed to the status quo. The two communities, Orma and Pokomo, can be regarded to have two distinct status quo - the pastoralist Orma and the crop-farming Pokomo. In search of water and grazing pasture for their livestock, the Orma invade the farms of the Pokomo along the Tana River Delta region thus leading into conflicts.

The structural conflict theory focuses on the competition between groups within society over scarce or limited resources. It, however, does not explain how these conflicts arise. In this regard, the study adopts the new-Malthusian to explain how population pressure and resource scarcity can lead to conflicts.

\subsubsection{The neo-Multhasian theory}

Natural resource access has been viewed as a security issue in the twenty-first century in many ways. The significance of natural resources in conflict has been examined from two perspectives: plenty (United States Institute of Peace, 2007, p11) and scarcity (United States Institute of Peace, 2007, p11). Empirical and theoretical literature presents a divergent view on the nexus between natural resources and conflicts. In an attempt to establish the most relevant explanation conflicts, certain scholars like Nathalie (2015) have theorized that conflicts are driven by the abundance of resources. In his work "Explaining occurrence of conflicts: clashes of cultures or abundance of resources?", Nathalie (2015) popularizes the resource abundance-conflict theory in which case an abundance rather than a scarcity of economic means, or natural resources, increases the risk of civil war emergence (Ibid:14). In a review of literature on natural resources and conflicts, Mildner, Lauster, and Wodni (2011) established that resources were the second-most conflict item in 363 conflicts recorded in 2010. As Mildner, Lauster, and Wodni (2011) argue, the reason resources are linked to conflict is that they occur together with other conflict items like territory, autonomy, ideology and predominance. In Sub-Saharan Africa, for instance, evidence shows that resources dominate conflict items far more than other regions of the world - in 2010, 38 percent of resource-based conflicts were from this region (HIIK, 2010). 
In support of the resource abundance-conflict theory, Christa and Erwin (2009) challenge the economic perception that abundance of natural resources leads to economic development without considering other links to existence of these resources. These authors, rather argue that in the 1990s, three dimensions emerged on how abundance of resources can negatively affect society. Christa and Erwin (2009: 651 - 652) claim that natural resource abundance has been associated with slower economic growth in some cases, violent civil conflicts, and undemocratic regime types. They offer empirical contribution from cross-section analysis as prove that dependence on natural resources tend to magnify the risk of violent conflicts among communities.

This study considered the second view which points to scarcity of natural resources as a cause of conflicts in Tana River County by adopting the neo-Malthusian theory. This theory disapproves Malthus view that rapid population growth would exceed resource base leading to environmental destruction and violent conflict (Gleditsch, Peter, Mikael, Margareta, \& Håvard, 2002). There are counter arguments to Malthus' view, some on the basis that on the global context, natural resources are not really scarce (Lomborg, 2001). Another argument is that even if some resources would get scarce, people can adopt to challenges posed by such scarcity.

In adopting the neo-Malthusian view on the link between the scarcity of natural resources and conflict, the study considers the premise that population-induced resource scarcity can cause violent conflicts (Henrik, 2005). The neo-Malthusians argue that factors like environmental degradation, resource depletion, and unequal resource access impoverish people (Colin, 2002). When this happens, the result is income inequality especially in lowincome countries. It is important at this juncture to note that, often, natural resources that are essential for societal survival are unevenly distributed. In this regard, the uneven distribution of resources can make communities feel deprived of livelihoods thus increasing the risk of societal conflict (Colin, 2002). In other cases, scarcity of some natural resources may occur, albeit temporarily. For instance, droughts and dry spells in Tana River County make water and grazing pasture become unevenly distributed thus making the Orma invade the Pokomo farms along the Tana Delta in search of the same.

Proponents of the neo-Malthusian theory like (Homer-Dixon, 1999) have identified different sources of resource scarcity that lead to conflict. This is the limitation with the structural conflict theory since it does not address the origin of natural resources-based conflicts. Homer-Dixon (1999: 48) argues that one of these variables is population growth, which is an important source to demand-induced scarcity. This is because when a resource base is constant, its availability per person diminishes since it has to be shared. This resonates well with scarcity of water and pastures in the Tana delta whose scarcity can and does trigger conflicts among the Orma and Pokomo communities. Homer-Dixon and Blitt (1998) argue that the livelihoods of large populations in lowincome countries are dependent on among other resources fresh water and cropland. However, this argument by (Lomborg, 2001) can be counter challenged on the grounds that this is not easily achievable in low-income countries. Such regions lack enough capacity to deal with environmental challenges or scarcity. Due to this challenge, Homer-Dixon (1999) and Kahl (2002) have argued that population growth leads to demand-based scarcity, the nexus between natural resource scarcity and conflict is real in low income countries like Africa. Demand-based scarcity in Tana River County can be as a result of migration resulting to conflicts and rivalry in the host community.

\subsection{Research Methodology}

The study adopted the mixed methods design through qualitative and quantitative viewpoints. According to (Johnson \& Larry, 2017) mixed methods approaches provide methodological flexibility and are adaptable to many study designs. Using Creswell's and Plano Clark's (2011) typology, the study adopted the convergent parallel design where "the quantitative and qualitative strands of the research are performed independently and their results are brought together in the overall interpretation" (Schoonenboom \& Johnson, 2017: 117). For this typology, cross-sectional survey design was used to collect data from household heads in Tana River County. This type of design made it possible to collect data to make inferences about the target population one point in time; cross-sectional surveys being snapshots of the populations about which they gather data (Babbie, 2012; Singleton \& Straits, 2011; Elliot, Fairweather, Olsen, \& Pampaka, 2016).

The study was carried out in Tana River County in two locations: Ngao in Tarasaa Division, and Kilelengwani in Kipini Division. The choice for this study locale was guided by the fact that the region has experienced persistent natural resource-based conflicts, particularly from 2013. In Kilelengwani for instance, the conflicts led to the death of 53 people, 9 of whom were police officers.

The target population were household heads from Ngao and Kilelengwani villages in Ngao and Kilelengwani divisions respectively. These are areas that have experienced frequent resource-based conflicts more than the other regions in Tana River County. Household heads were the ideal population to sample from since in Tana River County, they mainly control land either individually or as members of the council of elders. A study by Carranza, Katembu, and Miriti (2017) established that in Tana River, "the councils of elders were effective institutions...trusted to manage community land on behalf of the communities". The council of elders undertake land allocation and conflict resolution. This being the case, household heads were best placed to 
respond to how natural resource-based conflicts influence security in Tana River County.

Sampling was done through both probability and non-probability sampling. The first step in selecting the household heads was to determine how many participants shall be drawn from each location. Proportionate sampling was used to select study participants from the two locations. Ngao Location has 4,000 households and Kilelengwani has 4476 households (KNBS, 2019). Proportionately, Ngao contributed $47.19 \%$ while Kilelengwani contributed $52.81 \%$. since the desired sample is 382, the household heads from Ngao Location were 180 and 202 from Kilelengwani. The second step was to select the household heads to participate in the study. The researcher used the list of households for the two divisions from the Assistant Commissioners as a sampling frame. Through simple random sampling, the researcher selected the study participants using a random number generator. The key informants were selected purposively.

Data was collected through a questionnaire, an interview guide and a focus group discussion guide. The questionnaire was used to collect data from household heads, and it was self-administered or in some other cases, enumerators filled in the responses due to illiteracy of participants or low educational levels. The questionnaire was appropriate since it made it possible to examine the influence of resource-based conflicts on security in Tana River County. The interview guide collected data from key informants. Secondary data was collected from relevant reports, theses, dissertations, books, and journals. Relevant government reports and policy documents were reviewed to complement primary data.

The information gathered in the field will be classified into quantitative and qualitative categories, then verified for completeness, utility, and correctness. Through content analysis linked to the research goals, the qualitative data will be edited and categorized into themes and sub-themes. Qualitative data will be copied of verbatim and presented in prose form. The quantitative data will be edited, coded and entered into the Statistical Package for Social Sciences (SPSS) version 23 for windows for descriptive analysis based on study objectives to describe the influence of resource-based struggles on security management in Tana River County. Analyzed data was presented descriptively in form of figures and tables. All statistical measurements were performed within $95 \%$ confidence interval.

\subsection{Study Findings}

The background characteristics of the respondents are presented in Table .1.

Table 1: Background characteristics of the respondents

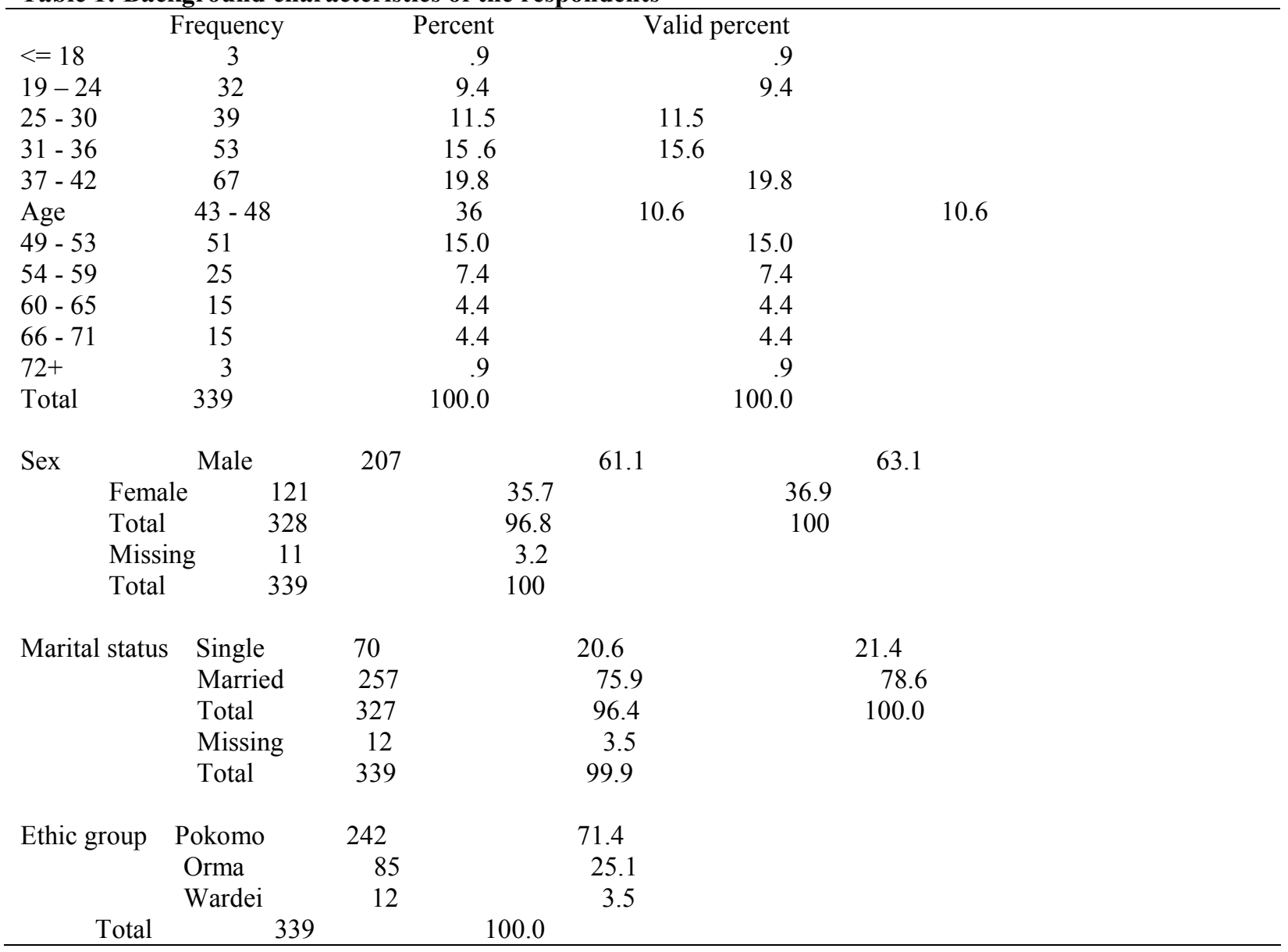




\begin{tabular}{lrrrr} 
Religion & Muslim & 115 & 33.9 & 34.0 \\
& Christian & 222 & 65.5 & 67.7 \\
Other & 1 & .3 & .3 \\
Total & 338 & 99.7 & 100.0 \\
Missing & 1 & .3 & \\
Total & 339 & 100.0 & 9.0 \\
Level of education & & & 12.0 \\
Primary Incomplete & 30 & 8.8 & 7.8 \\
Primary School & 40 & 11.8 & 37.2 \\
Secondary Incomplete & 26 & 7.7 & 22.2 \\
Secondary School & 124 & 36.6 & 6.6 \\
Tertiary College & 74 & 21.8 & 5.1 \\
University & 22 & 6.5 & 100.0 \\
None & 17 & 5.0 & \\
$\quad$ Total & 333 & 98.2 & \\
\hline$\quad$ Missing & 6 & 1.8 & 100.0 & \\
\hline
\end{tabular}

\subsubsection{Security threats associated with natural resource-based conflicts in Tana River County}

The objective of the study was to assess the security threats associated with natural resource-based conflicts in Tana River County. Data were collected from household heads and key informants. The study sought from participants the type of human security threats that were associated with natural resources in Tana River Country. Human security was categorized into three: personal security, community security, and environmental security. This categorization is based on the UNDP Human Development Report of 1994 and the HSU-OCHA (UN, 2009). The results are presented in the following sub-sections.

\subsubsection{Personal security threats}

Personal security was operationalized by identifying five indicators: physical violence, crime, terrorism, child labour and forced migrations. The results are presented in figure 1.

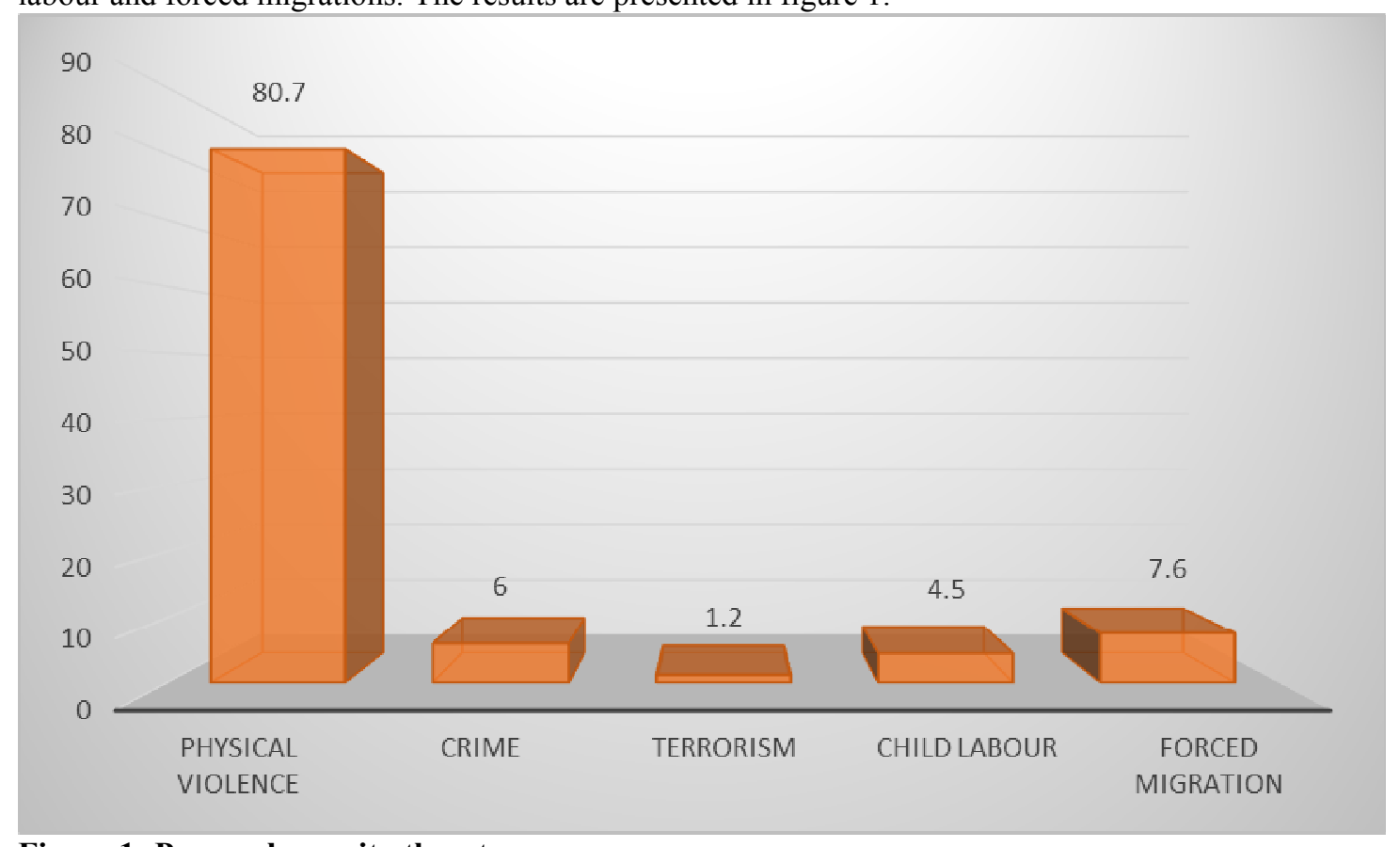

\section{Figure 1: Personal security threats}

The results show that 80.7 per cent of the participants cited physical violence as the common form of personal security experienced in Tana River County. These findings are in line with those of Owuor, Mauta, and Eriksen (2011), who conducted a research to look at climate variability and change adaptability. The study was confined to how pastoral and agropastoral communities interact in drought adaptation in the neighboring Mwingi Sub-county. One of the most important discoveries was that pastoralists and agropastoralists interacted when livestock moved to the plains during the rainy season and closer to the hill during the dry season. In Tana River County, for example, conflict between pastoralists and agropastoralists over shallow well access and dry-season grazing resulted in cattle and huma deaths. (Christine \& Will , 2010; Owuor, Mauta, \& Eriksen, 2011). 


\subsubsection{Community security threats}

The indicators for community security were inter-ethnic and religious threats, loss of land or cultural and natural heritage, disruption of cultural practices and deterioration of livelihoods. The results are presented in figure 2.

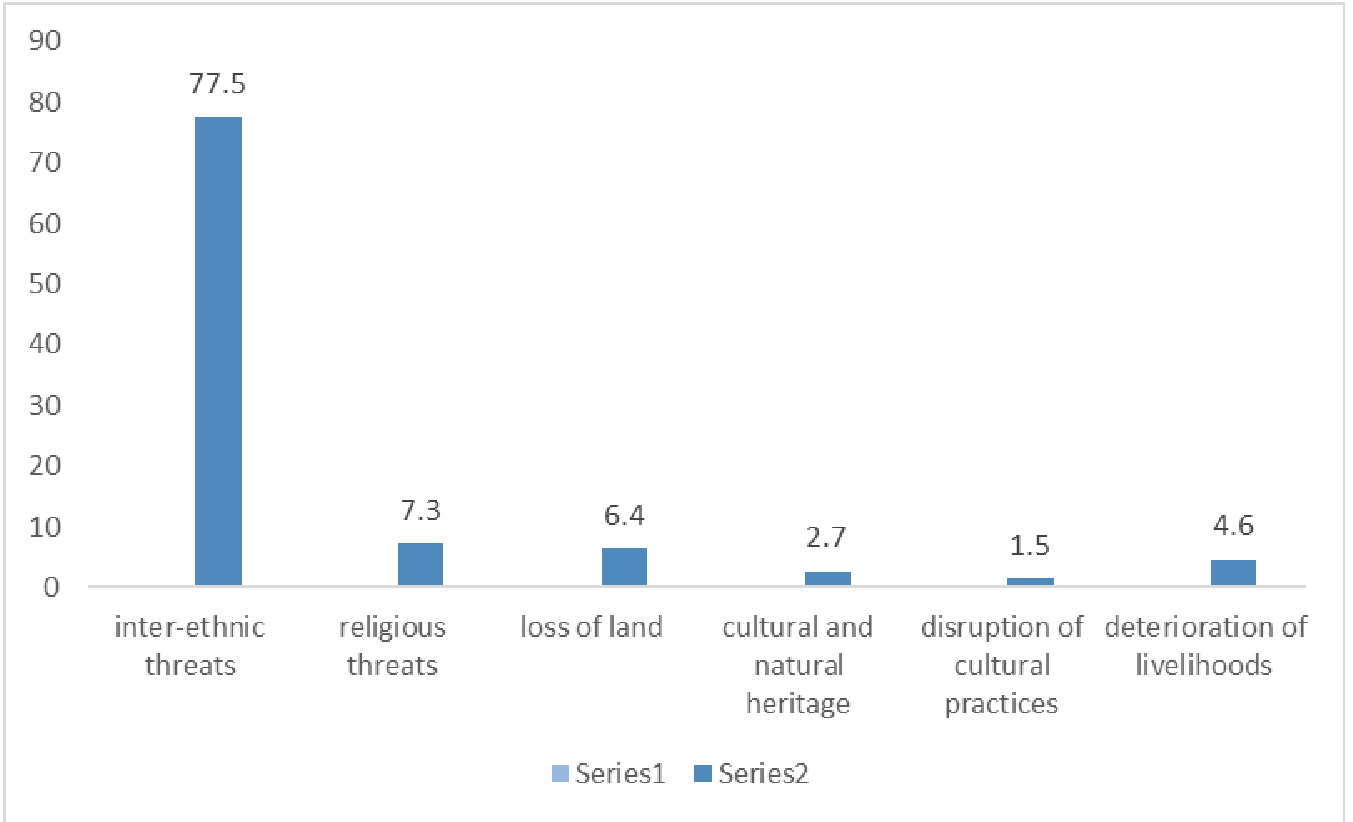

\section{Figure 2. Forms of community security threats in Tana River County}

The results show that the inter-ethnic threats were cited as the prevalent form of human security threat in Tana River County. Out of the six indicators of community security, 77.5 per cent of the participants indicated that inter-ethnic threats were associated with natural resources in the area. This can be explained by the interactions among various communities that are resident in Tana River County or move to the county in search of water and pasture for their animals. These findings are in agreement with observations in other related studies done in and out of Tana River County that these interactions among communities are not without problems. For example, Lind and Eriksen, (2006) observe that a period of violent raiding and attacks on Kamba settlements by Somali groups occurred especially during the dry seasons. In Tana River County, Nicholas , Jacqueline , and Simon (2009) observe that "... with no coherent planning to manage land use there were regular conflicts...," in Tana River County and the cite a case in 2012 clashes between the farmer Pokomo and pastoralist Orma communities resulted in the death of 286 people.

\subsubsection{Environmental security}

The third form of human security was environmental security. Environmental deterioration, resource depletion, natural catastrophes, and pollution were the indications. Figure 3 shows the final results.

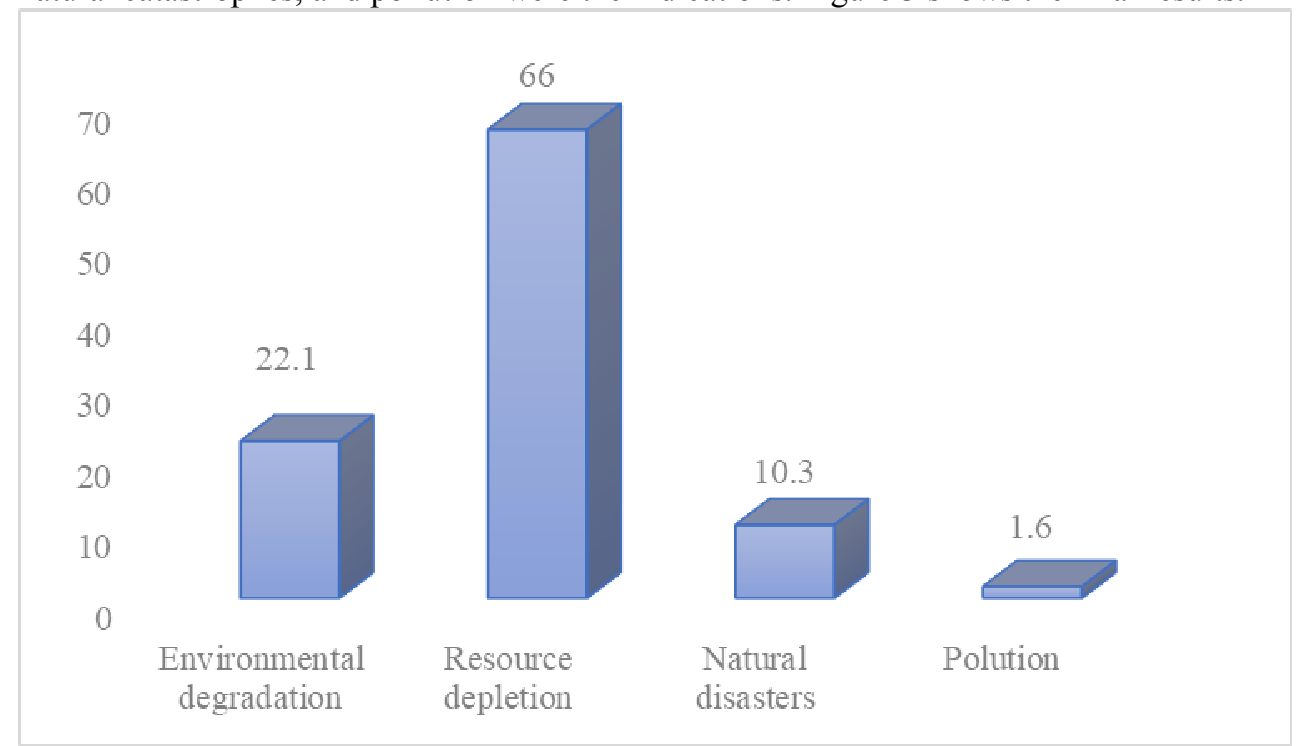

Figure 3. Forms of community security threats in Tana River County

The results in figure show that resource depletion was the most cited form of environmental security at 66 
per cent while environmental degradation was second at 22.1 per cent. Resource depletion and environmental degradation have implications on the security of Tana River County since both the farming and pastoral communities since there is a nexus between scarcity of natural resources and conflicts. These results are supported by observations of the key informants, thus:

The scarcity for grazing land and water points for the pastoralists in this area has led to conflicts. Also, the land tenure policies where the land is not demarcated. There is also restriction by the Kenya Forest Service which denies pastoralists entry into the forests to graze their animals (Key informant 2, Ward Commander]

Literature on environmental security views ecological processes and natural resources as sources or catalysts for conflict. In addition, as Scott and Thapa (2015) observes, scarcity of natural resources can act as barriers or limits to human well-being. When in abundance, natural resources act as means to mitigate or resolve insecurity.

These data support the study's second hypothesis, the neo-Malthusian theory. The outcomes of the study show that there is a relationship between natural resource shortage and conflict. Environmental deterioration, resource depletion, and uneven resource access, according to the neo-Malthusians, impoverish humans (Colin, 2002). Environmental degradation and resource depletion often leads to scarcity of some natural resources. For instance, dry spells make water and grazing pasture become unevenly distributed thus making the Orma invade the Pokomo farms along the Tana Delta in search of the same. Results show that scarcity of water and pasture had contributed to conflicts in Tana River County.

\subsubsection{Conflict management approaches used in Tana River County}

The third objective was to establish the various conflict management approaches used in Tana River County. The study established that the communities have a traditional system of governance charged with security management in Tana River County. To examine the influence of the peace committees, participants' responses were recorded using a five-point Likert scale. The first item measured the effectives of the peace committees in peacebuilding. The results are presented in figure 4.

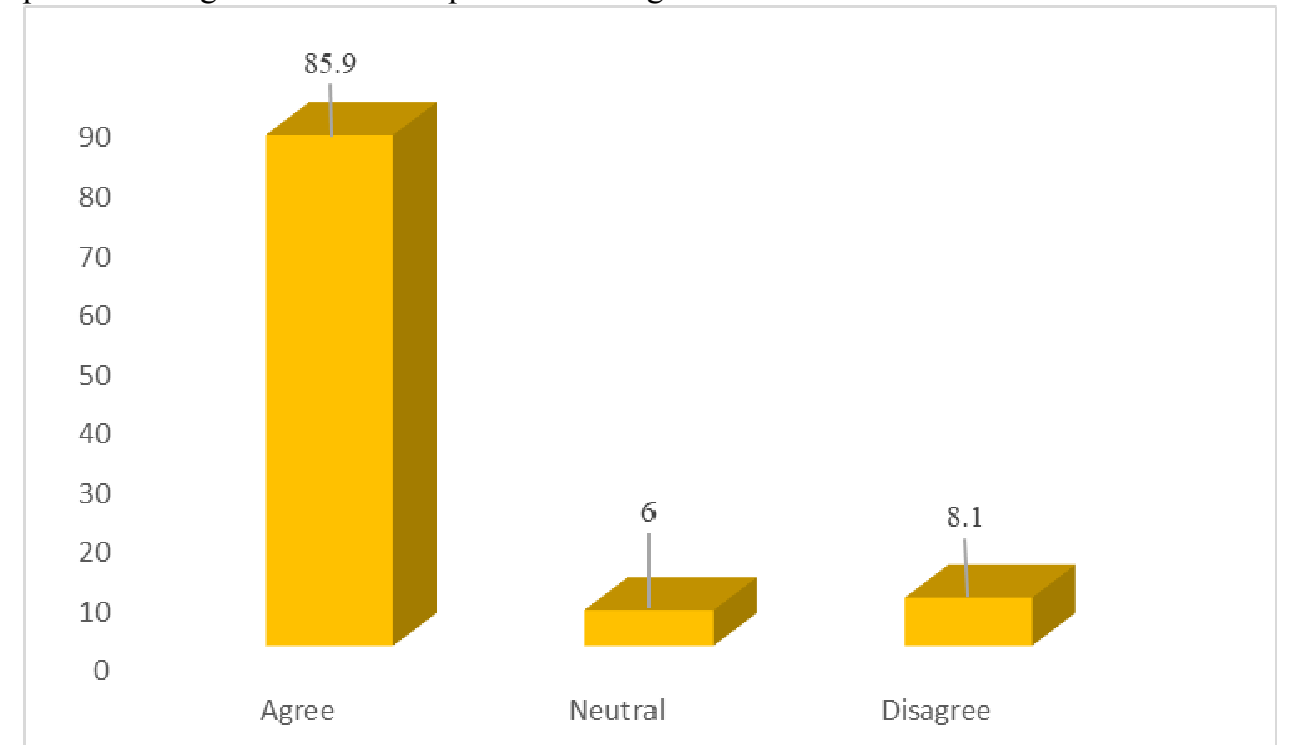

\section{Figure 4: Effectives of traditional peace committees in peacebuilding in Tana River County}

The results show that 85.9 per cent of the participants observed that traditional peace committees were effective in peacebuilding in Tana River County. Participants observed that the traditional system of governance was effective since 84.7 per cent of the participants felt that traditional leaders in Tana River County were major actors in the peace building process. Traditional systems of conflict management have been effectively employed to deal with land disputes in Zambia. Ajayi, et al. (2012) established that traditional chiefs were engaed in Zambia to manage land conflcits.

The results established that another 71.2 per cent of the participants observed that traditional leaders in Tana River County have been engaged in mediation when there were violent conflicts in the area. Overall, 69.2 per cent of the participants observed that the traditional system of governance in Tana River County was capable of ensuring security in the area. However, there were mixed opinions from the key informants on the effectiveness of the traditional peace committees:

The traditional peace committees are not effective because most of the leaders in these committees take ethnic sides and they have therefore lost credibility in the area [Key informant 1, Sub-county Police Commander]. 
This opinion differs from the observation by other two key informants who indicated that the traditional peace committees were effective. Key informant 2 (Headman) pointed out that the peace committees were partially effective. This was supported by key informant 3 , who stated thus:

The traditional system of governors, who we term as council of elders, are very instrumental in community matters...they are usually incorporated in peace and security committees. However, in extreme situations, you find that members of these committees fall back to their communities [sic], that is, they end up taking sides [Key informant 3, Deputy County Commissioner].

The existence of the peace committees was confirmed by key informant 1, who stated thus:

The interventions that have been adopted in Tana River County include peace committees. These are structured from the Sub-location level up to the county level.

There is also the use traditional council of elders. Other interventions used include having joint security meetings [key informant 1; Sub- County Police Commander].

On whether the peace committees were effective or not partially depended on the ethnic community. For example, 45.5 percent cent of participants from the Orma community agreed respectively that the peace committees were effective in dealing with conflicts in Tana River County. On the other hand, 83.7 per cent of participants from the Pokomo community agreed that the committees were effective. The relationship between ethnic group and opinion on effectiveness of peace committees was significant significant, $\chi^{2}(8, n=334)=17.6$, $p=.025$. However, this relationship was weak (Cramer's $\mathrm{V}=0.162)$. This association between ethnicity and opinion on effectiveness of security committees was observed by Kirchner (2013), who states that "Orma were convinced that peace committees were ineffective. Peace negotiations had, in their view, to be held by the elders. The members of peace committees were not seen as having authority and were said of not being serious about their peace efforts". Further, the study established that "members of the committees would pretend to promote peace, but in fact, as soon as they were with their own community, they would even incite people to fight" (Kirchner, 2013:89).

Traditional peace committees have been used elsewhere to a certain level of success. For example, Owuor, Mauta and Eriksen (2011) established that local peace committees worked in conjuction with the then provincial administration Mwingi District whenever conflicts arose between the Kamba community on one hand and the Orma and Somali communities. Pickmeier (2012) observed that peace committees were established in Tana River County in 2001. The peace committees then were formed to sentise people after the 2001 clashes, settle disputes and to engage people in finding solutions. Pickmeier (2012) notes that one type of conflict the peace committees would settle frequently were those between the Pokomo farmers and Orma pastoralist communities. Peace committees are also used in Tanzania and Uganda, where they are known as village committees in Tanzania and work closely with district officials to guarantee sustainable resource use, while in Uganda they are in charge of land disputes (Ogola, 2013).

The study also established that there were four conflict interventions that were commonly employed in Tana River County: traditional dispute resolution approaches, alternative dispute resolution, litigation, and police/community security meetings. The results are presented in figure 5.

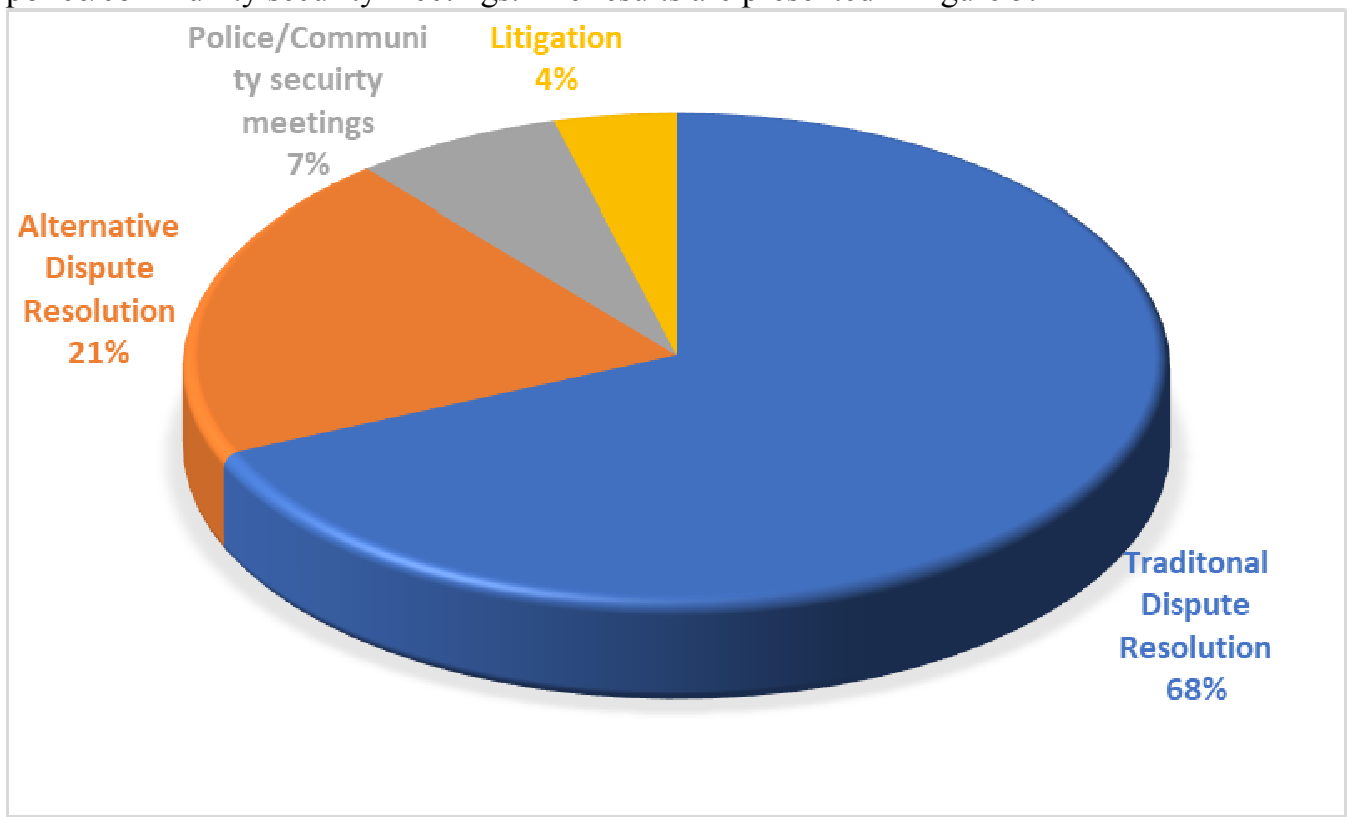

Figure 5: Conflict management approaches in Tana River County 
The results show that traditional dispute resolution (TDR) mechanism was cited as the most popular approach to other approaches at 79 per cent. Alternative dispute resolution (ADR) was cited by 21 per cent of the participants while 7 per cent and 4 per cent cited police/community security meetings and litigation respectively. These results renovate with other findings which observe that TDR and ADR were common approaches in conflict management. For example, (UNEP, 2015) observes that TDR are appropriate as many disputes on natural resources involve local actors and "require local knowledge to resolve...In numerous instances, customary mechanisms already exist that handle such disputes or have the capacity to do so". A key participant observed the following:

There are several interventions that are used in in tana River County include prosecution of offenders; both the pastoralists and farmers. As the National Police Service, we conduct security barazas. There is also community policing, use of peace committees as well as negotiation [key informant 2; ward commander].

The study compared the rating by participants on the effectiveness of the conflict resolution approaches in Tana River County through a five-point Likert scale. The results are presented in figure 6.

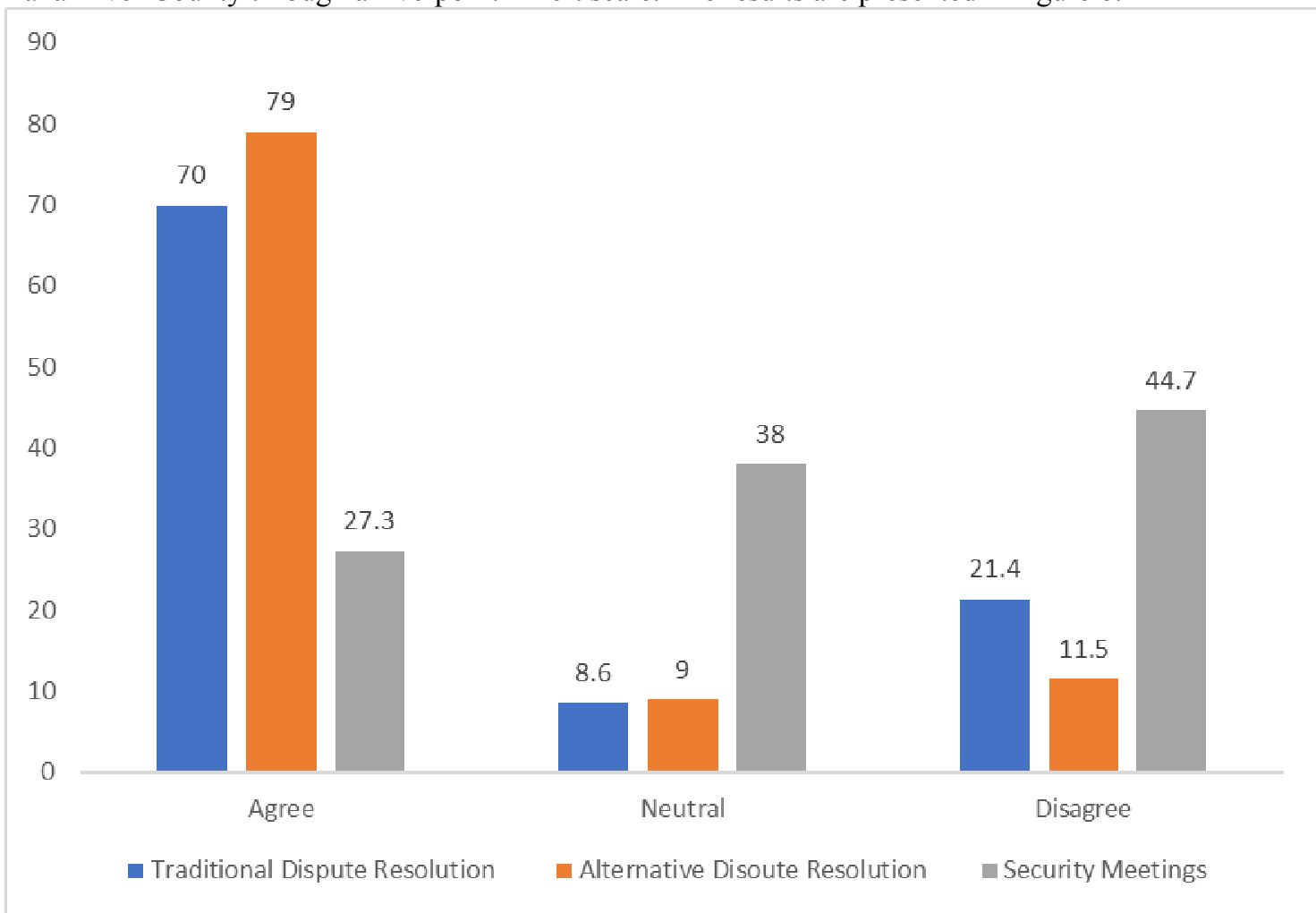

Figure 6: Rating of the effectiveness of the conflict resolution approaches in Tana River County

The results show that traditional dispute resolution (TDR) approaches and alternative dispute resolution (ADR) mechanisms were effective in Tana River County compared to security meetings between the police and community members. Results show 70 per cent and 79.5 per cent of participants agreed that TDR and ADR were effective while only 27.3 per cent agreed that security meetings between the National Police Service and community members in Tana River County.

Though the traditional dispute resolution approaches were cited as the most common in conflict resolution in Tana River County, there were some dissenting opinions. Participants were asked to rate the influence of TDR on security management in Tana River County. On the traditional peace committees, 13.8 per cent of the participants disagreed that they were effective in peace building while 13.9 per cent did not agree that the committees were major actors in the peace building process. In addition, 27.1 per cent of the participants disagreed that the peace committee members were engaged in mediation processes and thus were ineffective. Overall, 9.5 per cent of this category of participants observed that the traditional dispute resolution mechanisms at certain times fueled conflicts, especially on land disputes.

Oher studies have also observed that traditional dispute resolution mechanisms have failed, though for different reasons. Oli and Michael (2015) observed that traditional dispute resolution approaches were not appropriate in settling disputes for local communities. Thus, there was the attendant risk of violent conflict partly due lack of an impartial outsider to bring antagonistic. 


\subsection{Conclusion}

Mainly, two ethnic groups (the Pokomo and Orma) were at the center of the natural resources-based conflicts in Tana River County. The two clashes between the two communities were induced by conflicts over land and access to water. The underlying problem about the clashes is the communal ownership of land since there are no fixed statutory and individual property rights over land in Tana River County. Much as the farmer Pokomo community claim sole rights to their farms, the pastoralist Orma community have adopted the communal use of the area land consequently leading to armed conflicts. The study concludes that unless land adjudication was undertaken in Tana River County, natural resources-based conflicts shall persist. The fact that the land rights in the Tana delta remain unclear, the Pokomo and Orma communities shall persistently claim the same land since only few people have title deeds. Such a scenario creates a different land tenure system as well as multiple ownership claims which is a likely trigger of frequent violence in Tana River County. This is despite the formation of peace committees, natural resource management committees, as well as joint security meetings and apprehension of offenders.

\subsection{Recommendations}

The study suggests the following recommendations as a solution to natural resources-based conflicts in Tana River County. The following solutions could be adopted.

The Ministry of Agriculture in collaboration with the Ministry of Water and Sanitation and Irrigation to generate natural resources policies that will create the existence of sufficient water points in the hinterland. This would keep livestock owned by the pastoralist communities outside of the delta thus mitigating the water needs of both communities. The Ministry of Water and Sanitation and Irrigation could revive the collapsed irrigation schemes in order to create livelihoods for community members thus reducing the tensions between the dominant Pokomo and Orma communities.

The Ministry of Lands and Physical planning should formalise the land tenure system in Tana River County. This should be done with full participatory of all stakeholders and fair representation from both sides (age, gender and religion). This would go a long way in sharing the resources between the pastoralist and agropastoralists. As part of first line management approach to illicit arms used for self defence, it is hereby recommended that National Government Officers in the region to advise residence of the county to surrender the illicit arms to the security apparatus.

\section{References}

Antonia , E., \& Benedikt, K. (2005). Negotiation and mediation techniques for natural resource management. Rome, Italy: FAO.

Babbie, E. (2012). The practice of social research (13th ed.). Belmont, CA: Wadsworth Cengage Learning.

Badurdeen , F. A., \& Omalenge, N. W. (2015). Government Strategies as Contributing Factors to Resource Conflicts Among Pastoralists and Farmers in the Tana River County, Kenya. Addis Ababa University: Institute for Peace and Security Studies (IPSS).

Bavinck , M., Pellegrini , L., \& Mostert, E. (2014). Conflicts over natural resources in the Global South: Conceptual approaches. CRC Press.

Collier, P., \& Hoeffler, A. (2009). Testing the Neo-con Agenda: Democracy in Resource-Rich Societies. European Economic Review, 53, 293-308.

Creswell , J. (2012). Educational research: Planning, conducting, and evaluating quantitative and qualitative research (4th ed.). Upper Saddle River: NJ: Pearson Education.

Creswell, J. W., \& Plano Clark, V. 1. (2011). Designing and conducting mixed methods research (2nd ed.). Los Angeles: Sage.

Daniel , S., Walker , G., \& Emborg, J. (2012). The Unifying Negotiation Framework: a model of policy discourse. Conflict Resolution. Q. 30, 3e31.

Elfversson, E. (2013, April 8-20). Third Parties, the State, and Communal Conflict Resolution: A Comparative Study of Evidence from Kenya. The Thomas Ohlson Memorial Conference. Uppsala.

Elliot, M., Fairweather, I., Olsen, W., \& Pampaka, M. (2016). A Dictionary of Social Research Methods. Oxford University Press.

Fabrizio, B., Juan, J. G., \& Miguel , R. (2006). The Socilogy of social structure. In B. Bryant, \& D. Peck, 21st century sociology: A reference handbook (pp. 162 - 170). Newbury: Sage.

FAO. (2017). The community land rights of women and youth in Tana River and Turkana counties: A synthesis report. Nairobi: Food and Agriculture Organization of the United Nations.

Fenn, P. (2012). Introduction to Civil and Commercial Mediation. London.: Charterred Institute of Arbitrators.

Frankel, A. J. (2010). The Natural Resource Curse: A Survey.HKS Faculty Research Working Paper Series, RWP10-005. John F. Kennedy School of Government, Harvard University.

Jensen, D., Matthew, A. R., \& Brown, O. (2010). From conflict to peacebuilding: The role of natural resources 
and the environment. Nairobi: UNEP.

Kasimbazi, E. (2017). Land tenure and rights for improved land management and sustainable development. UNEP.

Katembu, Q., Miriti, K., \& Carranza, F. (2017). The community land rights of woemn and youth in Tana River and Turkana Counties: A syntheis report. Nairobi: FAO.

Kipkemoi , S., Nyamasyo , G., \& Musingi, J. (2017). Natural resource based conflicts in Tana River county, Kenya . International Academic Journal of Human Resource and Business Administration, 2(3), 599 - 610.

Kirchner, K. (2013). Conflicts and politics in the Tana Delta, Kenya: An Analysis of the 2012-2013 clashes and the General and Presidential election 2013. African Studies Centre, Universiteit Leiden: Unpublished Masters Thesis.

KNBS. (2018). Basic report on well-being in Kenya. Nairobi: Kenya National Bureau of Statistics.

KNBS. (2019). 2019 Kenay population and housing census Volume I: Population by County and Sub-County. Nairobi : Kenya National Bureau of Statistics.

Martin , J. L., \& Lee, M. (2015). Social Structure. (J. D. Wright, Ed.) International Encyclopedia of the Social \& Behavioral Sciences, 22(2), 713-718.

Nicholas , G., Jacqueline , M., \& Simon, D. (2009). Voices from the land: Restoring soils and enriching lives. Nairobi: United Nations Environmental Programme.

Ogola, S. A. (2013). Land and natural resource conflicts in transboundary agroecosystem management project, Kagera basin. FAO.

Oli , B., \& Michael , K. (2015). Addressing natural resource conflicts: Working towards more effective resolution of national and sub-national resource disputes. Energy, Environment and Resources.

Owuor, B., Mauta, W., \& Eriksen, S. (2011). Sustainable adaptation and human security: Interactions between pastoral and agropastoral groups in dryland Kenya. Climate and Development, 3(1), 42 - 58.

Ryan, T. (2013). Sample Size Determination and Power. John Wiley and Sons.

Schoonenboom, J., \& Johnson, R. B. (2017). How to Construct a Mixed Methods Research Design. Köln Z Soziol, 2(69), 107-131.

Scott , C. A., \& Thapa, B. (2015). Environmental security. In Ellen Wohl (ed.) Oxford Bibliographies in Environmental Science. New York: Oxford University Press.

Singleton, R. A., \& Straits, B. C. (2011). Approaches to Social Research (5th ed.). Oxford University Press.

Terer , T., Ndiritu, G. G., \& Gichuki, N. N. (2004). Socio-economic values and traditional strategies of managing wetland resources in Lower Tana River, Kenya. Hydrobiologia, 527, 3-14.

UN. (2009). Human security in theory and practice. New York: Human Security Unit, UN.

UNEP. (2015). Natural Resources and Conflict: A Guide for Mediation Practitioners . Nairobi: UNEP.

United States Institute of Peace. (2007, September 14). Natural resources, conflict, and conflict resolution. Washington, DC: United States Institute of Peace.

Weiss, T. (2004). Guns in the borderlands. Reducing the demand for small arms. Pretoria: Institute for Security Studies. 